\title{
Elaboration and validation of diagrammatic scale for lettuce powdery mildew
}

\author{
Guilherme de Resende Camara ${ }^{1}$; Laedio Magno Busato ${ }^{1}$; Bárbara Favalessa Almeida ${ }^{1}$; Willian Bucker Moraes ${ }^{1}$
}

${ }^{1}$ Department of Plant Production, Agricultural Sciences Center, Federal University of Espírito Santo - UFES, 29500-000, Alegre, ES, Brazil. Autor para correspondência: Guilherme de Resende Camara (grcamara@hotmail.com)

Data de chegada: 14/02/2017. Aceito para publicação em: 07/08/2017.

$10.1590 / 0100-5405 / 175851$

\section{ABSTRACT}

Camara, G.R.; Busato, L.M.; Almeida, B.F.; Moraes, W.B. Elaboration and validation of diagrammatic scale for lettuce powdery mildew. Summa Phytopathologica, v.44, n.2, p.116-121, 2018.

Powdery mildew, caused by Oidium sp., is a disease of great importance in hydroponic crops of lettuce. However, in Brazil, there is scarce research focused on the epidemiological study of this disease, as standardized methods are necessary to quantify the disease severity in hydroponic systems. Thus, a logarithmic scale was developed at levels of $0.37,1,2,4,8,16,32$ and $74 \%$ injured leaf area, testing the parameters accuracy and precision. The proposed scale was validated by eight evaluators, of whom four were experienced and four were inexperienced, and they used 50 leaves showing symptoms of the disease at different severity levels, previously measured with the aid of QUANT ${ }^{\circledR}$ software. Two evaluations were performed with a 48-h interval, in which the evaluators visually estimated distinct sequences of leaves. Linear regression was used to determine the accuracy and the precision of each evaluator. The proposed scale showed satisfactory results of accuracy and precision, and despite the inexperience of four evaluators, absolute errors were in the range of $8 \%$ after training. The proposed scale was adequate to estimate the severity of powdery mildew on lettuce.

Keywords: Oidium sp, Lactuca sativa L., severity, epidemiology.

\section{RESUMO}

Camara, G.R.; Busato, L.M.; Almeida, B.F.; Moraes, W.B. Elaboração e validação de escala diagramática para mancha de oídio em alface. Summa Phytopathologica, v.44, n.2, p.116-121, 2018.

A mancha de oídio, causada por Oidium sp., é uma doença de grande importância em cultivos hidropônicos de alface. Entretanto, no Brasil, são escassas as pesquisas voltadas ao estudo epidemiológico desta doença, visto que métodos padronizados são necessários para quantificar a severidade da doença em sistemas hidropônicos de cultivo. Assim, propôs-se o desenvolvimento de uma escala logarítmica aos níveis de $0,37,1,2,4$, $8,16,32$ e $74 \%$ de área foliar lesionada, testando-se os parâmetros de acurácia e precisão. A escala proposta foi validada por oito avaliadores, sendo quatro experientes e quatro inexperientes, os quais fizeram uso de
50 folhas que apresentavam sintomas da doença em níveis diferentes de severidade, mensurados previamente com auxílio do software QUANT ${ }^{\circledR}$. Foram realizadas duas avaliações com intervalo de 48 horas, nas quais os avaliadores visualmente estimavam sequências distintas de folhas. Através de regressão linear pode-se determinar a acurácia e a precisão de cada avaliador. A escala proposta apresentou resultados satisfatórios de acurácia e precisão e, apesar da inexperiência de quatro avaliadores, os erros absolutos após o treinamento se encontraram na fixa de $8 \%$. A escala proposta mostrouse adequada para estimativa da severidade da mancha de oídio da alface.

Palavras-chave: Oidium sp., Lactuca sativa L., severidade, epidemiologia.

Lettuce (Lactuca sativa L.) originated from the Mediterranean region (11) and is widely known in Brazil (17) as the leafy green vegetable of greatest economic importance in the national scene (18; 21). According to the Brazilian Vegetable Yearbook, the states of São Paulo, Rio de Janeiro and Belo Horizonte are the largest domestic producers (19).

In Brazil, lettuce is the main crop produced hydroponically and its production sites are generally close to the major urban centers (5). Protected cultivation allows a controlled cultivation environment and consequently promotes an increase in productivity (7).

It is produced throughout the year, but winter and spring offer the most favorable weather conditions (21); the variety of available lettuce cultivars is wide, showing different types, shapes, sizes and colors, of which the curly lettuce is most consumed (19). However, according to Castoldi et al. (4), there are a large number of biotic and abiotic factors in the production chain of this vegetable, which hinder production and affect productivity.
In hydroponic crops, since leaves are not wetted through irrigation systems, which would remove the pathogen structures, powdery mildew (Oidium sp.) is a common disease of vegetable crops and is characterized by the presence of whitish structures of the pathogen on both sides of the leaf, which evolve to a grayish color, causing chlorosis and, subsequently, necrosis of tissues, affecting the visual appearance of leaves and depreciating the final product $(7 ; 12 ; 15 ; 20)$.

Despite the great importance of this disease, epidemiological studies on damage quantification are nonexistent, which requires the development of standardized methodologies that feature the high reliability of the data generated based on the quantification of the disease severity in the field.

Considering that powdery mildew is one of the major leaf diseases affecting this crop in hydroponic systems, its intensity is best expressed based on the diseased leaf area and the severity or the proportion of the leaf area affected by the pathogen. However, two significant terms are related to the reliability of the visually estimated severity data: 
accuracy and precision. Accuracy indicates how close the estimated value is to the real value, while precision indicates the variation or the repeatability associated with the estimates.

There are numerous diagrammatic scales to evaluate the severity of leaf diseases in agronomic crops like tomato (Lycopersicum esculentum Mill.) (1), beans (Phaseolis vulgaris L.) (6) citrus (Citrus spp.) (16), soybean (Glycine max (L.) Merr.) (9) and corn (Zea mays) (3; 23). However, for leaf diseases in lettuce, only two scales are described in the literature, O'Brien \& Van Bruggen (14) for lettuce downy mildew (Bremia lactucae), and Gomez et al. (10) for Cercospora leaf spot (Cercospora longissima). Given the above-mentioned facts, this study aimed to establish a logarithmic diagrammatic scale from data collected in the field and, subsequently, evaluate its effectiveness in determining the severity of powdery mildew in lettuce.

\section{MATERIAL AND METHODS}

The experiment was conducted from August to December 2015 at a commercial property located in the county of Santa Maria de Marechal, Espírito Santo State, and at the Epidemiology and Management's Laboratory of Agricultural and Forest Plants (LEMP), located in Alegre City, Espírito Santo State.

In the end of the crop cycle, 350 leaves of lettuce, variety Vanda, showing different severity levels of characteristic powdery mildew stains, were collected from a commercial hydroponic crop, which became part of a database. From these, 50 leaves were individually scanned, and 300dpi images were transferred to a microcomputer. Then, each leaf was analyzed for the proportion of impaired area, using the QUANT ${ }^{\circledR}$ software (22), according to the discriminant analysis method, which indicated the actual disease severity (\%). According to the Weber-Fechner law of visual acuity, intermediate severity values were determined to finally establish the diagrammatic scale. This method was chosen for its more reliable results; other methods may yield divergent results due to the similarity between the lesion color for this pathosystem and the color of naturally aged leaves.

To validate the proposed diagrammatic scale, eight people were selected and divided into two groups, one group consisting of four inexperienced people in terms of severity assessment and the other group consisting of four experienced people for the same purpose. Each group assessed 50 leaves of the sample and assigned a visual score for severity without the assistance of any attribute. After 46 hours, both groups of evaluators had access to the diagrammatic scale proposed in this study and, after 48 hours of the completion of the first test, they used the proposed scale to assess again the severity of the 50 leaves, which were displayed in an order different from that in the first test.

The severity data estimated by the eight evaluators, with and without the proposed diagrammatic scale, were compared with the actual severity data obtained by linear regression using the Quant ${ }^{\circledR}$ software. Thus, the performance of each evaluator as to accuracy and precision could be determined; precision was obtained based on the coefficient of determination of the equation $\left(\mathrm{R}^{2}\right)$ and accuracy was obtained based on the approximation of parameters ' $a$ ' and ' $b$ ' of the equation, compared according to t-test with parameters 0 and 1 , respectively.

Accuracy and precision data were correlated to the variance of absolute errors in order to validate the efficiency of the scale that would improve the performance of evaluators in estimating the severity of powdery mildew in lettuce $(8 ; 10)$.

Simple linear regression analysis was adopted to determine the accuracy and the precision of visual estimates, defining the most appropriate regression models for each assessment in relation to the data obtained from Quant ${ }^{\circledR}$ software. To compare the accuracy and the precision of each evaluator, with and without the proposed diagrammatic scale, the parameters intersection (a), slope (b) and coefficient of determination $\left(\mathrm{R}^{2}\right)$ were used. Evaluators for whom estimates of ' $a$ ' and ' $b$ ' resulted in regression equations with parameters ' $a$ ' and ' $b$ ' not statistically different from 0 and 1 , respectively, were considered more accurate and more precise than evaluators for whom equations allowed the model adjustment with $\mathrm{R}^{2}$ values above $90 \%$.

\section{RESULTS}

The results obtained from the analysis of the actual severity of sampled leaves were tabulated and used to determine the severity frequency (Figure 1). The maximum severity value found for lettuce leaves was $73.89 \%$. Values above $70 \%$ may be found in the field since in

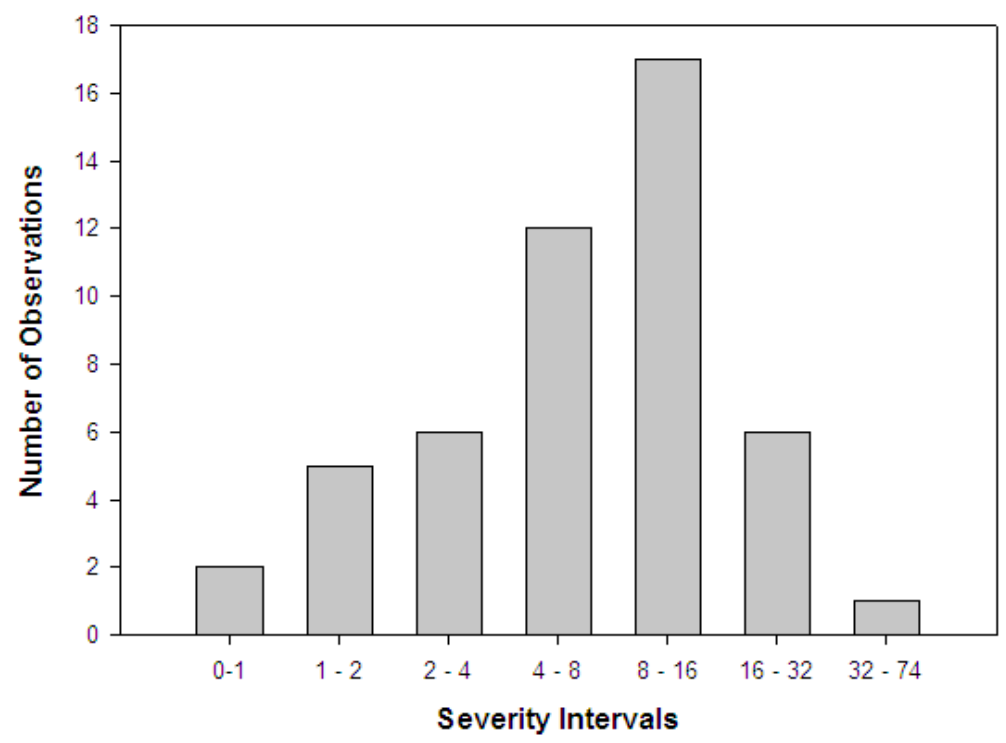

Figure 1. Severity frequency of powdery mildew caused by Oidium sp. in lettuce (Lactuca sativa L.) assessed in injured area at different intervals. 
the initial phase of colonization by the pathogen the leaf does not enter senescence and, before the leaf blade deterioration, a large percentage of leaf area is taken by the mycelium originated from the colonization.

The lowest severity value found in the analyzed sample was $0.37 \%$. The diagrammatic scale prepared for powdery mildew of lettuce showed the following values: $0.37,1,2,4,8,16,32$ and $74 \%$ severity (Figure 2$)$, using the two extreme values $(0.37$ and $74 \%$ ) and the other values plotted by logarithmic scale, adjusted to the observed severity frequency.

Initially, for lower severity values, the mildew stain shows typical round lesions that increase in size with the advance of the disease. However, for higher severity values, with the advance of the disease, larger irregular necrotic areas are formed, as well as necrotic tissue near the ribs, resulting in complex and differentiated lesions.

To evaluate the efficiency of the proposed scale, considering the severity values estimated by each evaluator, with and without scale, the residual severity was calculated (estimated severity minus real severity) and graphs were plotted for each evaluator with each evaluation method (Figures 3 and 4).

For all evaluators, severity level increases when estimated without the diagrammatic scale. This can be best seen in Figures 3 and 4, where the residual values in the first column (estimate without the scale) are above zero or null threshold plotted in the middle of the graph. However, this severity overestimation is minimized when the proposed diagrammatic scale is employed, which can be noted by comparing the residual values plotted in the second column (estimate with scale) with the residual values plotted in the first column. This comparison can be based on the same line of Figures 3 and 4, where the evolution of each evaluator during the scale validation process can be found.

However, this severity overestimation is minimized when the proposed diagrammatic scale is used, and this fact is best seen when the residual values plotted in the second column (estimate with the scale) are compared with the residual values plotted in the first column. This comparison can be based on the same line of Figures 3 and 4, where the evolution of each evaluator during the scale validation process can be noted.

According to the simple linear regression curve, coefficients ' $a$ ' and ' $b$ ' were determined together with the coefficient of determination $\left(\mathrm{R}^{2}\right)$
Table 1. Accuracy and precision represented by the intersection (a), slope (b) and coefficient of determination $\left(\mathrm{R}^{2}\right)$ for the evaluation of the severity of powdery mildew caused by Oidium sp. in lettuce (Lactuca sativa L.). Evaluations were performed by inexperienced and experienced evaluators, with and without the use of the diagrammatic scale.

\begin{tabular}{lcccccc}
\hline & \multicolumn{3}{c}{ Without scale } & \multicolumn{3}{c}{ With scale } \\
\cline { 2 - 7 } Evaluatory & $\mathbf{a}$ & $\mathbf{b}$ & $\mathbf{R}^{\mathbf{2}} \mathbf{( \% )}$ & $\mathbf{A}$ & $\mathbf{b}$ & $\mathbf{R}^{\mathbf{2}} \mathbf{( \% )}$ \\
\cline { 2 - 7 } & \multicolumn{6}{c}{ Inexperienced } \\
\hline 1 & 2.62 & 1.05 & 79 & 0.02 & 0.99 & 95 \\
3 & $7.21^{*}$ & 1.21 & 85 & 0.48 & 1.02 & 94 \\
4 & $5.76^{*}$ & 1.07 & 86 & $0.75^{*}$ & 0.95 & 96 \\
\hline & $3.09^{*}$ & 1.23 & 85 & 0.41 & 1.03 & 96 \\
\hline 1 & & \multicolumn{7}{c}{ Experienced } \\
3 & $3.29^{*}$ & 1.06 & 93 & 0.32 & 1.01 & 99 \\
4 & $5.78^{*}$ & 0.89 & 81 & 0.51 & 1.04 & 94 \\
\hline & $6.57^{*}$ & 0.93 & 82 & $0.78^{*}$ & 0.97 & 98 \\
\hline
\end{tabular}

* Linear model parameters significantly different from 0 and 1 for intersection (a) and slope (b), respectively.

for each evaluator, with and without the scale. The data were displayed in Table 1 and subjected to t-test for comparison of the parameters ' $a$ ' and ' $b$ ' with the patterns 0 and 1 , respectively.

The classification of an excellent evaluator is based on the error of estimates, which should be within a range of $5 \%$ of the actual estimated value (13). For a good evaluator, this error should reach a maximum range of $10 \%$. Thus, both inexperienced and experienced evaluators can be considered good evaluators when using the diagrammatic scale proposed in this paper. According to the absolute error data shown in Figure 4, experienced evaluators who used the scale can be considered to range between good and excellent evaluators.

Experienced evaluators were more precise and accurate than

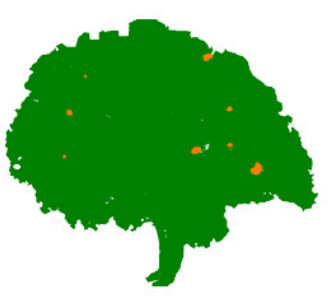

$0,37 \%$
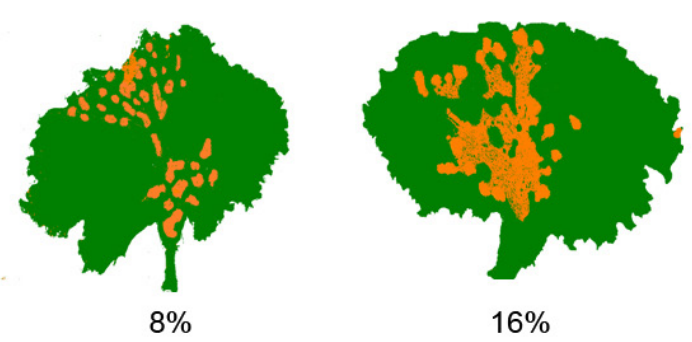

$16 \%$

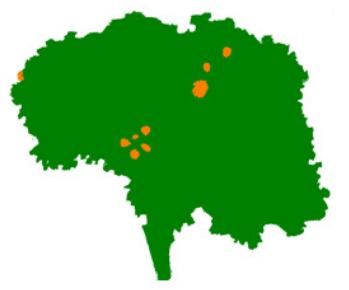

$1 \%$
$2 \%$

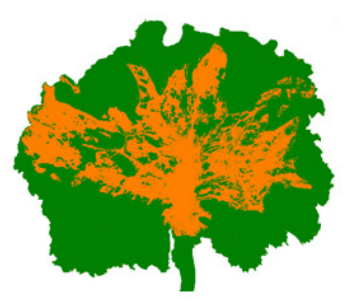

$32 \%$

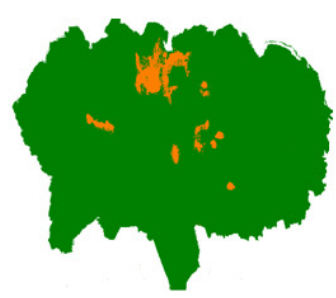

$4 \%$

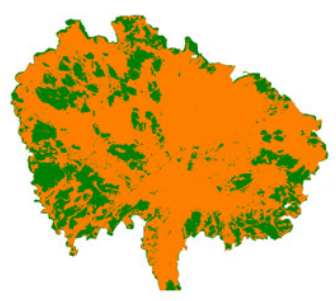

$74 \%$

Figure 2. Diagrammatic scale for powdery mildew (Oidium sp.) in lettuce. 

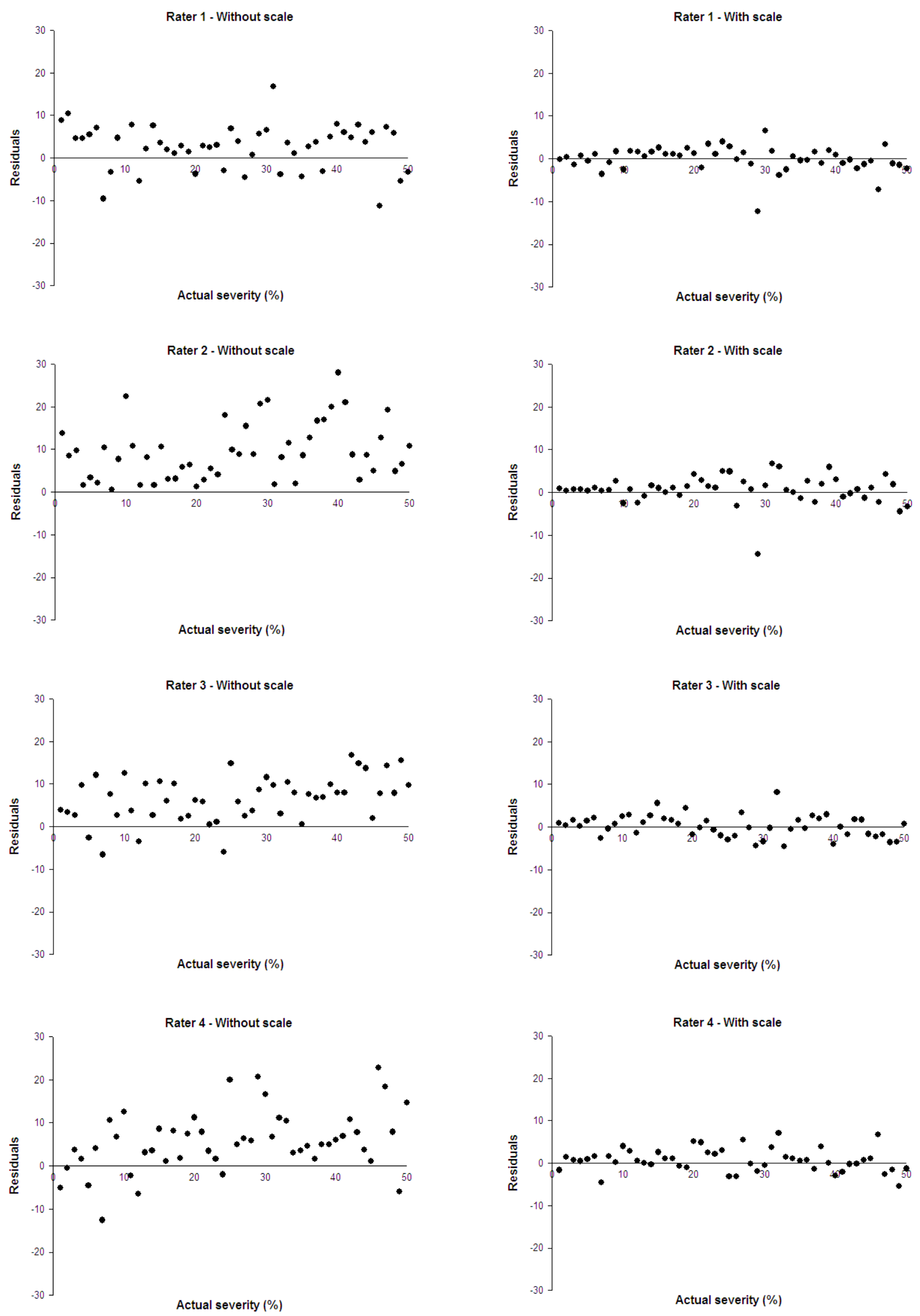

Figure 3. Absolute errors (Residual values - estimated severity minus actual severity) assigned to groups of inexperienced evaluators for assessment with and without the scale. 

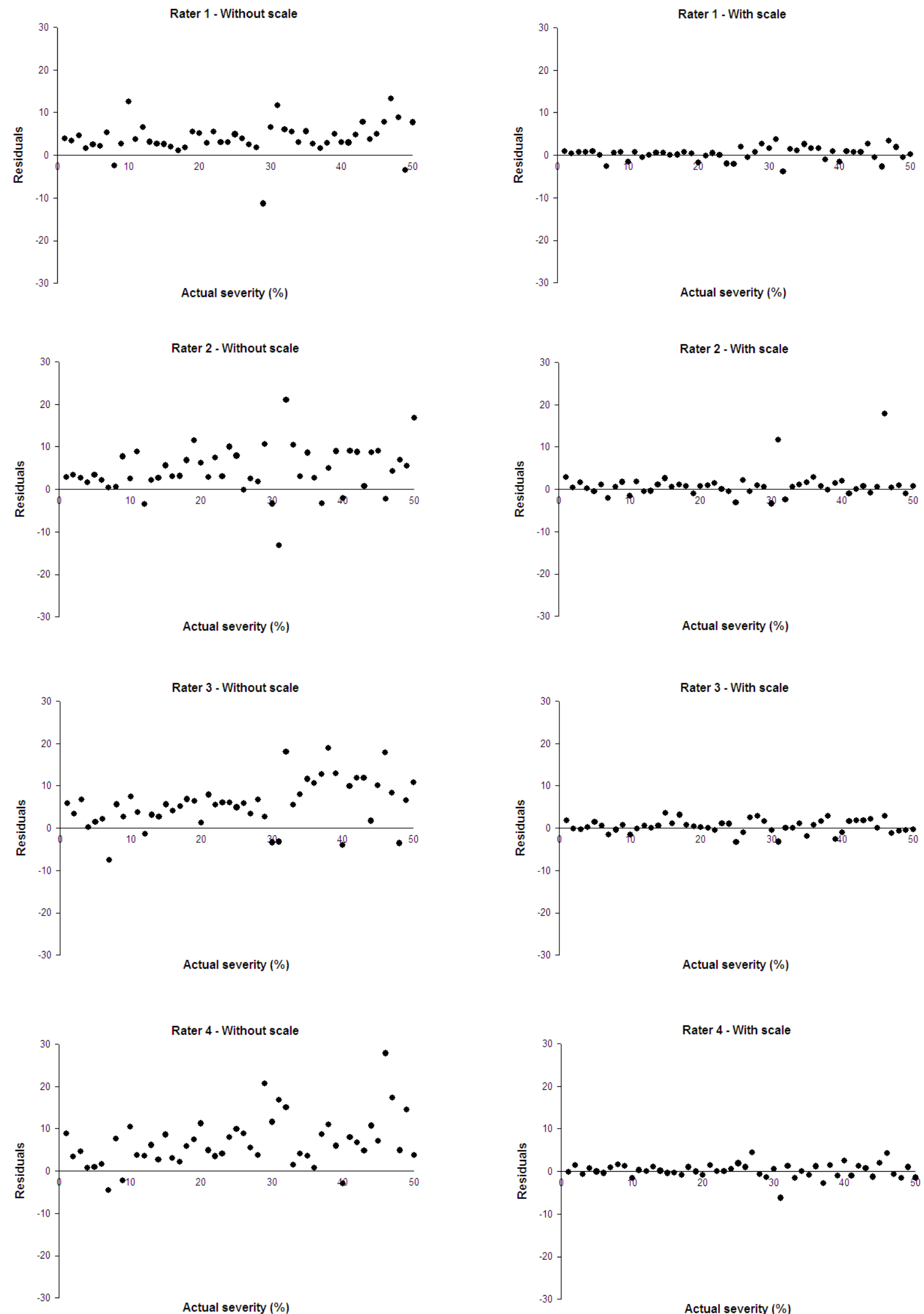

Figure 4. Absolute errors (Residual values - estimated severity minus actual severity) assigned to groups of experienced evaluators for assessments with and without the scale. 
inexperienced ones, especially before the use of the scale. This was also reported by Boff et al. (1), Campbell \& Madden (2) and Gomez et al. (10).

The use of the scale influenced especially the accuracy of evaluators, for which values of ' $a$ ' and ' $b$ ' were closer to 0 and 1 , respectively (Table 1 ).

Based on the results obtained in this study, the proposed diagrammatic scale showed good characteristics such as: ease to use and good precision and accuracy, which makes it a very useful tool to quantify the severity of the disease in the field. To use the proposed scale, the producer must divide the production into quadrants and, from these, randomly select leaves that present symptoms or signs of the disease, to estimate the severity or the proportion of the leaf area compromised by the action of the pathogen and adopt disease management measures.

\section{ACKNOWLEDGMENTS}

We would like to thank "Conselho Nacional de Desenvolvimento Científico e Tecnológico" (CNPq, Brasília - DF, Brazil) and "Coordenação de Aperfeiçoamento de Pessoal de Nível Superior" (CAPES, Brasília - DF, Brazil) for financial support.

\section{REFERENCES}

1. BOFF, P.; ZAMBOLIM, L.; VALE, F.X.R. Escalas para avaliação de severidade de mancha de estenfílio (Stemphylium solani) e da pinta preta (Alternaria solani) em tomateiro. Fitopatologia Brasileira, Brasília, v.16, n.4, p.280-283, 1991.

2. CAMPBELL, C.L.; MADDEN, L.V. Introduction to Plant Disease Epidemiology. New York: John Wiley \& Sons, 1990.

3. CAPUCHO, A.S.; ZAMBOLIM, L.; DUARTE, H.S.S.; PARREIRA, D.F.; FERREIRA, P.A.; LANZA, F.E.; COSTA, R.V. Influence of leaf position that correspond to whole plant severity and diagrammatic scale for white spot of corn. Crop Protection, Surrey, v.29, n.9, p.1015-1020, 2010.

4. CASTOLDI, R.; CHARLO, H.C.O.; DALPIAN, T.; MELO, D.M.; BOTELHO, A.P.; BRAZ, L.T. Identification of new Bremia lactucae races in lettuce in São Paulo state. Horticultura Brasileira, Brasília, v.30, n.2, p.209-213, 2012

5. CORRÊA, E.B. Controle biológico da podridão radicular (Pythium aphanidermatum) em cultivos hidropônicos. 2009. 133f. Tese (Doutorado em Agronomia) - Faculdade de Ciências Agronômicas - UNESP, Botucatu.

6. DÍAZ, C.G.; BASSANEZI, R.B.; BERGAMIN FILHO, A. Desenvolvimento e validação de uma escala diagramática para Xanthomonas axonopodis pv. Phaseoli em feijoeiro. Summa Phytopathologica, Botucatu, v.27, n.1, p.35-39, 2001.

7. FORNER, C.; GALVÃO, J.A.H.; IOSTI, R.; PANNUTTI, L.E.R.; VIS-
CONTI, A.; BETTIOL, W. Controle do oidio do tomateiro com Bacillus subtilis e Bacillus lichenoformis. In: Congresso Paulista de Fitopatologia, 34., 2011, Campinas. Resumos... Campinas: Grupo Paulista de Fitopatologia, n.142, 2011.

8. GODOY, C.V.; CARNEIRO, S.M.T.P.; IAMAUTI, M.T.; PRIA, M.D.; AMORIM, L.; BERGER, R.D.; BERGAMIN FILHO, A. Diagrammatic scales for bean diseases: Development and validation. Journal of Plant Disease and Protection, Rostock, v.104, n.4, p.336-345, 1997.

9. GODOY, C.V.; KOGA, L.J.; CANTERI, M.G. Diagrammatic scale for assessment of soybean rust severity. Fitopatologia Brasileira, Brasília, v.31, n.1, p.63-68, 2006.

10. GOMEZ, A.M.A.; MICHEREFF, S.J.; MARIANO, R.L.R. Elaboração e validação de escala diagramática para cercosporiose de alface. Summa Phytopathologica, Botucatu, v.30, n.1, p.38-42, 2004.

11. LEBEDA A.; DOLEŽALOVÁ I.; KŘÍSTKOVÁ E.; MIESLE-ROVÁ B Biodiversity and ecogeography of wild Lactuca spp. in some European countries. Genetic Resources And Crop Evolution, Netherlands, v.48, n.2, p.153-164, 2001.

12. LOPES, C.A.; QUEZADO-DUVAL, A.M.; REIS, A. Doenças da alface Brasília: Embrapa hortaliça, 2010. p.31-33.

13. NUTTER JR., F.W. Disease Pro: a computer program for evaluating and improving a person ability to assess disease proportion. Phytopathology, St. Paul, v.79, n.1, p.1135, 1989.

14. O'BRIEN, R.D.; VAN BRUGGEN, A.H.C. Accuracy, precision, and correlation to yield of disease severity scales for corky root of lettuce. Phytopathology, St. Paul, v.82, n.1, p.91-96. 1992.

15. REIS, A. Atenção para o oidio em hortaliças. Brasília: Embrapa hortaliça, 2011. Disponível em: <http://www.cnph.embrapa.br/paginas/ imprensa/releases/oidio em hortalicas.html>. Acesso em: 06 dez. 2015.

16. RODRIGUES, J.C.; NOGUEIRA, L.N.; MACHADO, M.A. Elaboração e validação de escala diagramática para leprose dos citros. Summa Phytopathologica, Botucatu, v.28, n.2, p.192-196, 2002.

17. RODRIGUES, R. de Q. Avaliação microbiológica e dos sistemas de gestão da inocuidade produtiva de alface orgânica no sul do Brasil. 2013. 78f. Dissertação (Mestrado em Ciência e Tecnologia de Alimentos). Universidade Federal do Rio Grande do Sul, Porto Alegre.

18. SALA, F.C.; COSTA, C.P. da. Retrospectiva e tendência da alfacicultura brasileira. Horticultura Brasileira. Vitoria da Conquista, v.30, n.2, p.187194, 2012.

19. SANTOS, C.E; KIST, B.B.; CARVALHO, C, REETZ, E.R.; MULLER, I.; BELING, R.R.; POLL, H. Anuário brasileiro de hortaliças 2015. Santa Cruz do Sul: Gazeta Santa Cruz, v.1, n.1, p.1-45, 2015.

20. SILVA, M.S.C; LIMA NETO, V. C. Lettuce diseases in hydroponic cultivation in the metropolitan Green belt of Curitiba, Paraná State, Brasil. Scientia Agrária, Curitiba v.8, n.3, p.275-283, 2007.

21. TOFOLI, J.G.; DOMINGUES, R.J.; FERRARI, J.T. Mildio e mofo branco da alface: doenças típicas de inverno. Instituto Biológico, São Paulo, v.76, n.1, p.19-24, 2014.

22. VALE, F.X.R.; FERNANDES FILHO, E.I.; LIBERATO, J.R. QUANT A software plant disease severity assessment. In: $8^{\text {th }}$ International Congress of Plant Pathology, 2003. Christchurch. Anais Christchurch: New Zealand, [s.n.], p.105, 2003.

23. VIEIRA, R.A.; MESQUINI, M.; SILVA, C.S.; HATA, F.T.; TESSMANN, D.J.; SCAPIM, C.A. A new diagrammatic scale for the assessment of northern corn leaf blight. Crop Protection, Surrey, v.56, n.1, p.55-57, 2014 